\title{
The Phenomenon of Extremism in Religion in Muslim Life: An Analysis of Its Roots, Causes and Nature
}

\author{
Thameem Ushama ${ }^{1}$ \\ ${ }^{1}$ Department of Usul al-Din and Comparative Religion, Faculty of Islamic Revealed Knowledge \& Human \\ Sciences, International Islamic University Malaysia, Kuala Lumpur, Malaysia \\ Correspondence: Thameem Ushama, Jalan Sungai Pusu, 53100 Gombak, P. O. Box 10, 50728 Kulala Lumpur, \\ Selangor, Malaysia. Tel: 60-36-196-5550. E-mail: ushama_thameem@yahoo.co.uk; \\ thameem@iium.edu.my
}

Received: April 24, 2014 Accepted: May 15, 2014 Online Published: June 24, 2014

doi:10.5539/ass.v10n14p239

URL: http://dx.doi.org/10.5539/ass.v10n14p239

\begin{abstract}
This paper strives to analyse the roots, causes and nature of extremism in Muslim life from a contemporary Muslim perspective. Its scope is limited to historical, ideational and psychological roots of contemporary extremism among Muslim individuals and organizations, regardless of whether they live as the majority or minority in their country. It employs the qualitative method, focusing on content analysis of the writings of Muslim scholars and observations of extremists as they resort to activities that lead to fanaticism or obsession in their words and deeds. It is hoped this will awaken Muslims from their ignorance and raise their consciousness to know the history to enable them to correct themselves from their flaws or errors should they resort to any extremist tendencies in their intentions, interactions, interpretations, actions, articulations, analyses, speeches, sermons, dialogues, debates and writings or teachings, either consciously or unconsciously, whether in academic or social or political or religious or interfaith discourses. Lastly, it provides a conclusion and recommendations.
\end{abstract}

Keywords: roots, extremism, ideation, psychology, cause, nature

\section{Introduction}

In this era of globalization, the world is characterized by rapid developments where knowledge is regarded as a prerequisite. Due to advanced level of consciousness, education is believed to be an essential tool. Unlike previous decades, today it is considered as necessary for prosperity, success and global harmony. Life devoid of proper education is purposeless and useless. Information and communication technology has opened several avenues to obtaining all kinds of knowledge without hardship; for instance, people rely on websites and electronic channels in their pursuit of knowledge. It is undeniable that the majority of channels provide benefits. Everyone expresses admiration for scientific inventions and achievements. Like all kinds of knowledge, religious knowledge is also disseminated through these modalities. There is great appreciation for the media for their contributions to developments. This is from one perspective. One does not deny it.

However from another perspective, some industries which disseminate information and impart education are biased. Some websites are desperate in serving certain groups with preposterous objectives. Some blogs fabricate truths with no rules to govern their deliberations. Some bloggers have no concerns for ethics in broadcasting news and analysing views; they have no sympathy for people of other religions and their faiths. There is enormous distortion of religious messages and teachings, regardless of religion. Islam is no exception. It is the target of criticisms without justifications and evidence. It is projected as an extremist religion with violence as its foremost agenda. Its faithful adherents, i.e. the Muslims, are portrayed as fundamentalists, militants and extremists; even those who endeavour for Islamic revival through peaceful means are accused of resorting to extremism in human relations, interactions, attitudes and discourses, subject to surveillance and condemned to be scheming to topple regimes and resorting to sabotages.

It is irrefutable that some Muslims are extremists. Islamic traditions severely condemn them. Though the number of extremists is insignificant, it is exaggerated to advocate that the majority are extremists. As the existence of the phenomenon of extremism in religion is tangible, this paper strives to analyse the roots, causes and nature of extremism in religion, particularly in the Muslim life. It aims to awaken Muslims towards realization and raise their consciousness of early Muslim history to enable them to correct the flaws should they resort to extremist 
tendencies in speeches, interpretations, actions, articulations, sermons, references, writings and teachings, either consciously or unconsciously, whether in academic, religious, social or political discourses.

The methodology applied in this study is qualitative. As such, it employs content analysis of the writings, statements, speeches and observations of extremists' way of life as they resort to activities leading to extremism. The scope of the study is limited to historical, ideational and psychological roots of extremism among Muslims and religious organizations, regardless of whether they live as the majority or the minority in their country.

Commencing with an introduction in Section One, the second section refers to the history of Muslims to identify some of its roots towards heading to unhealthy situations in the community. The third section focuses on ideational roots that seem to be the impetus for the growth of extremist tendencies among Muslim youth where teachings of twentieth century revivalists are believed to be causing misunderstandings, especially the discourse on the concept of al-häkimiyyah (sovereignty) and its application in Muslim societies. The fourth section discusses the psychological roots of extremism where analysis is made to see to what extent events in the Muslim world or the West have resulted in the germination of extremist tendencies among the youth in the fourth quarter of the twentieth century and the beginning of the third millennium. The fifth section highlights the circumstances causing extremism and the final section refers to the nature of extremism. It ends with a conclusion and recommendations to eradicate this phenomenon.

\section{Historical Roots of Extremism}

According to Muslim scholars, the manifestation of extremism is not a recent phenomenon; it is as old as religion itself (Al-Luwayhaqīi, 1992, p. 92). History discloses that heavenly messages and prophetic teachings were affected by it. Muslim scholars have discussed this and responded in different periods in order to eliminate extremism, excessiveness, fanaticism or obsession in religion in Muslim life. But there were differences in approaches and methods of responses of the audience to the call of the Prophets. Many responded positively; some were adamant and obstinate; of course, some turned to be extreme and created disturbances, dissensions and turmoil by disregarding the messages of the Prophets.

Historically, one such example of this phenomenon of extremism is what Prophet Nūh (peace be upon him) experienced from his community where his followers transgressed God's prescribed limits and injunctions by elevating a group of righteous people to a state of godhood (ulühiyyah), thus undermining the teachings of Prophet Nūh (peace be upon him), particularly the concept of monotheism. At a later time, another scriptural evidence of extremism from the Muslim perspective is the manifestation by the children of Israel; they exaggerated and distorted the divine message by interpolating the revealed text and misguiding the adherents and devotees of their religion (Al-Luwayhaqī 1992, p. 92). Because they transgressed the limits in relation to their understanding of the true teachings of God, He prohibited the People of the Scripture (ahl al-Kitäb) from extremism or excessiveness by stating this in two Qur'ānic verses of al-Nisā': 171 and al-Mä'idah: 77, the Qur'ān being the Muslim Holy Scripture (henceforth, the Scripture).

From the Scripture's exposition on the phenomenon of extremism of earlier communities, it is evident that extremism had occurred even during the time of Prophet Muhammad (henceforth, the Prophet) (peace be upon him) where people posed challenges to his call to believe in the Oneness of God, inclusive of Arab leaders and elites who insulted the Prophet (peace be upon him) by fabricating his message and integrity, plotting to kill him until he had to migrate to Medina. Had there been no extremist interpretations in understanding the true nature and attributes of God, the Scripture would not have referred to such a phenomenon. In relation to extremism, events that took place, according to Muslim scholars, can be classified into two categories; the first is practical extremism while the second is ideological extremism.

Practical extremism usually appears in a manner often repeated in any situation or circumstance due to behaviours or activities of individuals in different societies. This element of practical extremism does not occur due to any historical root; rather, an individual invents it due to misconceptions or emotional attachment to doctrines, sects, schools of thought or even political parties or schools of jurisprudence and it is possible to occur in any situation, environment or milieu.

Ideological extremism can be analysed based on historical roots because it existed in Muslim communities. It was due to this phenomenon of extremism that much bloodshed has taken place, including wars and homicides. Extremism has historical connectivity where excesses have emanated from others as a result of imitation without realizing their relevance to contemporary situations and their consequences. Extremism also has an intellectual link to the past where contemporary modes of extremism conformed to older modes. These modes of ideological extremism existed in early Muslim societies. One such example of ideological extremism that remains as a seed for contemporary extremism was witnessed during the prophetic period on the initiative of Hurqūs ibn Zuhayr 
al-Sa ${ }^{c}$ dī, a Companion known as Dhū al-Khuwayșirah al-tamīmī, who kindled the fire of turmoil clandestinely, protested against the Prophet (peace be upon him) in his distribution of booties or spoils of war (Al-Dimashqī, 2002, Vol. 2, p. 173), participated in Iraqi expedition, joined the bandwagon of the Kharijites only to be killed in the end (Al-Shawkānī, n. d., Vol. 7, p. 185).

The event referring to turmoil (fitnah) is mentioned in a Prophet's tradition (Muslim, 1987, Vol. 4, p. 1499). It mentions 'breaking of a door' (in Arabic, kasr al-bāb) which metaphorically refers to the assassination of ${ }^{c}$ Umar, the second Caliph of the Islamic state and the actual beginning of a turmoil, a symbol of extremism, according to Muslim historians and it is narrated that biased persons guided by personal interests instigated others to take revenge against ${ }^{\mathrm{C}} \mathrm{Uthmān}$ ibn ${ }^{\mathrm{c}} \mathrm{Affān}$, the third Caliph of the Islamic state for the assassination of ${ }^{\mathrm{c}}$ Umar till leaders extended their hands and killed him. His assassination then, ignited the fire of violent turmoil where differences emerged between the Companions of the Prophet (peace be upon him). After this incident, a group of people realized the need for retaliation for the assassination of ${ }^{c} U$ thmān while others suggested delaying it until the power of the State was stable and strong (Jālī, 1406 AH, pp. 29-30). Then, the Battle of Camel took place representing struggles influenced by differences between the Companions. In this battle, ${ }^{c} \overline{\mathrm{A}}$ 'ishah, the Prophet's widow was on one side and his son in-law, ${ }^{c} A l \bar{i}$ ibn Abī Țâlib, the fourth Caliph of the Islamic state was on the other. Historians argue that righteous Muslims did not initiate this campaign; rather, groups with vested interests stimulated its operation, leading to serious consequences. Hence, this was the introduction of extremism in the Muslim society.

Then after the Battle of Camel, the Battle of Șiffīn surfaced between ${ }^{c} A l \overline{1}$ with his adherents and $\mathrm{Mu}^{\mathrm{c}} \overline{\mathrm{a}}$ wiyyah with his followers. This battle led to a great impact on the spread of turmoil, leading to the emergence of sectarianism. This turmoil resulted in two extreme sects known as the Kharijites and the Rafidites (Ibn Taymiyyah, 1372 AH, Vol. 13 and 32, p. 308). Both sects committed numerous excesses. They deviated from the Prophet's practices and wisdom, never bothered about unity, integrity and dignity of early Muslims and reached the climax of emotion. Examples of their transgressions are discussed next.

To begin with, on the issue of allegiance, the Kharijites transgressed the boundaries in relation to the notion of disavowal or guiltlessness of the Companions of the Prophet (peace be upon him). They seceded from supporting ${ }^{\mathrm{c}}$ Alī. The first notable secession was when a group of ${ }^{\mathrm{c}}$ Alī's soldiers at the Battle of Siffin who objected to any form of arbitration at the battle, protested that the judgment should be left to God alone before leaving the main army. They were joined on a later occasion by other supporters of ${ }^{c} A l \bar{l}$. Their beliefs were by no means uniformed as they were divided into a number of sub-sects, some increasingly fanatical and exclusivist in teaching, saying for example, that grave sinners would go to Hell and that they thereby placed themselves outside the community, that non-Kharijites were infidels and thus could be killed.

The Rafidites exceeded the limits in their allegiance to ${ }^{c} \mathrm{Al} \overline{\mathrm{l}}$, his offspring and their successors. They were also known as Imāmiyyah which were one of the three most important Shī ah groups. They were so-called due to their rejection of the leadership of Caliph Abu Bakr. They believed that the Prophet (peace be upon him) explicitly declared ${ }^{\mathrm{c}} \mathrm{Al} \overline{\mathrm{i}}$ as his replacement. They also held that most of the Companions of the Prophet (peace be upon him) went astray when they did not make allegiance to ${ }^{\mathrm{c}} \mathrm{Ali}$. Both the Kharijites and the Rafidites were unanimous in charging people who disagreed with them or their interpretations as infidels (Al-Shahristānī, 1381 $\mathrm{AH}, \mathrm{pp} .114-138$ ), which was one of the serious problems facing that society.

Gradually, there emerged other sects called Murji'ites, Qadarites and $\mathrm{Mu}^{\mathrm{c}}$ tazilites which perpetuated extremist tendencies. This research is thus focused on exploring whether extremist tendencies of the contemporary age are the product of classical extremism or not. Those who raised this question believe that contemporary extremists' views are in conformity with extremists of the past to a great extent, particularly the Kharijites and the Rafidites. This inference is endorsed by the majority of researchers (Al-Bahansāwī, 1985, p. 77).

In addition, those who subscribe to the view that contemporary extremists are influenced by the Kharijites argue that it is in the structural form and can be traced to the Rafidites. Some of the past extremist tendencies were [1] charging people who committed grave sins as infidels, [2] seceding people from the society (Al-Dujaylī, 1393 AH, p. 80), [3] charging the residents as infidels, leaving the immigrants on their own (Al-Shahristānī, $1381 \mathrm{AH}$, Vol. 1, p. 121), [4] making the notion that the lands of the Muslims were the lands of the unbelievers, thus bloodshed was permissible (Al-Baghdādī, n. d., p. 84) and [5] having emotional reaction or judgment (Jārullāh, n. d., p. 116).

When these issues are clarified with authentic evidence, it can be inferred that contemporary extremists benefit from the Kharijites and the $S^{-1}{ }^{-1}$ ites. In relation to this, the perceptions of scholars are rather different. Some are inclined to believe that contemporary extremists benefit from the Kharijites and their thoughts and this is one of 
the foundations, which influences their views, particularly among Muslim youth. Al-Bahansāwī (1985, p. 77) mentions that the principles of contemporary extremists are drawn from the Kharijites as endorsed in "Judhür al-fitnah fì al-firaq al-Islāmiyyah mundh 'ahd al-Rasūl hattā ightiyāl al-Sādāt" where arguments indicate that the turmoil of today is influenced by the interpretations of classical Muslim sects.

However, other academics are more inclined to the view that contemporary extremists do not benefit from the thoughts of the Kharijites and the $\mathrm{Sh}^{-1}$ ites; rather, it is a peculiar scenario that conforms to the thoughts, leading to devastating results (Al-Sāmrā'i, 1986, p. 8). Despite this difference, it is undeniable that some extremists have studied these sects and are influenced by their elucidations, keeping them as their framework as they explore new thoughts and cite them as the authoritative source and evidence in their discourses (Al-Sāmrā'i, 1986, p. 8).

Some scholars argue that extremism does not have any link with the thoughts of Kharijites and Rafidites or any other early sects. They view that circumstances and milieus in which extremists' views have originated demonstrate that it is not easy to have access to writings that discuss issues of sectarianism. One analyst who condemns extremism argues that when he discusses this matter with an academic, the response that he gets is that it is improbable for the roots of extremism to come from the Kharijites. According to him, issues in relation to extremism are products of prison cells and Muslim jurisprudence far away from books that never advocate or favour this tendency and whatever Muslim youth finally deduce is based on their individual reasoning (ijtihād), drawing from the Scripture and Traditions of the Prophet (peace be upon him) (Al-Sāmrā'i, 1986, p. 12).

In observing the discourses of contemporary Muslim thought and issues in light of religion, one can detect extremism or exaggeration. Emotional or unilateral arguments give rise to circumstances for the occurrences of extremism. Indeed, there were no principles among people of earlier generations in relation to extremism. The majority of individuals that resort to extremism today, if not all, are in the state of ignorance or unknowledgeable about Islamic Religious Sciences and have not read earlier writings on key issues of religion. Therefore, when it is attributed that their opinions are found in a book (al-Milal wa al-Nihal) and towards this end other books as well, they answer that they have never heard about this book and some people remark that they have heard about it but have never read it (Al-Sāmrā'i, 1986, p. 12). Upon referring to such opinions, those who are engrossed in extremism feel that the origins of extremism are the Kharijites (Al-Bahansāwī, 1985, p. 179). Extremists at a later stage and particularly the aspirants for contemporary political leadership are aware of the knowledge and opinions of the Kharijites and they probably benefitted from them.

Some proponents of the extremist perspective have already explained about the Kharijites and other sects who hold identical views (Al-Sāmrā'i, 1986, p. 12). Leaders imbued with extremism prohibit their followers and loyalists from reading books on history. There is no clear justification for this except the fear of knowing the history of the Kharijites and their opinions (Al- ${ }^{\mathrm{c}} \overline{\mathrm{A}}$ bidīn, 1984, p. 260). The developments of their ideas and strong proofs at later stages are evidence of their deeds in relation to earlier opinions. Some of the interpretations advanced by extremists such as extremism in charging a perpetrator of sins as an infidel are somehow nearer to evidence advanced by the Kharijites.

Likewise, their extremism in blaming imitators (muqallidūn) of early religious views is almost similar to the form of what has been written by al-Shawkānī and Ibn Hazm in criticizing imitation with a difference of opinions of extremists and these two scholars without acknowledging them. Subsequently, the impacts of classical sects on contemporary extremists are discussed below. Upon explaining them, the secrets behind the similarities between the opinions of the Kharijites and contemporary extremists can be unveiled. The first is similarity of the ideational method (manhaj al-fikr $\overrightarrow{\text { ) }}$ of these two segments. Indeed, the ideational method employed by these two segments lead us to reach the truth. The second is similarity of the ideational climate between these segments. Indeed, the ideational circumstances in which the Kharijites lived and the ideational circumstances in which contemporary extremists live seem to be similar in some respects. Both are poisoned and this is obvious from their ignorance. The Scripture is read without proper comprehension. The ideational development of these two segments is closer to each other where extremism is manifested by charging Muslims as infidels, then developing fanatical theories in a manner where extremists do not truly conform to Islamic fundamental principles and essentials. The beginning of their extremism is charging rulers as infidels, followed by other extremist activities.

The Kharijites never took into consideration the fundamentals of religion; instead, they stimulated emotional feelings and sentiments in relation to issues such as no rule except for God's in the beginning, later charging people as infidels, fighting and killing those who did not apply the rules of God. In the process, the Kharijites formulated opinions regarding problems that influenced others or were unilateral and biased concerning issues like the institution of Imāmah (imamate) and perpetrators of grave sins and passed a legal ruling that they were 
infidels (Jālī, 1406 AH, p. 47).

\section{Ideational Roots for Extremism}

Generally, opinions and thoughts are not severed from roots. There is link between early roots and later thoughts. In order to understand the true scenario, ideational roots are divided into two types. The first is ideational root of opinions that gives rise to the majority opinions. The second is shortcomings or flaws in the ideational structure represented by [1] ignorance, which means lack of knowledge, inadequacy or deficiency and [2] imperfection or defectiveness of the methodology. On this note, it is ideal to elaborate extremism in the life of contemporary Muslims so that the reality and nature of extremism can be understood.

\subsection{The Concept of Al-Hākimiyyah (Sovereignty) and the Phenomenon of Extremism}

For Muslims, submission or surrender or subservience is only for God. They believe that it is cosmic law. The surrender is absolutely to His legal rulings, one of the obligations of Islam and requirements of confession that there is no deity worthy to be worshipped or served but God and Muhammad is His Messenger as stated in the Scripture, "It is not fitting for a Believer, man or woman, when a matter has been decided by God and His Messenger, to have any option about their decision: if anyone disobeys God and His Messenger, he is indeed on a clearly wrong Path" (Qur'ān, $a l-A h z \bar{a} b$, verse no. 36). The assertion of this basic creed is mentioned in the Scripture in three modes.

First is the enumeration mode (uslüb al-hașr) where the limitation or restriction is explicit; that sovereignty is for God alone as stated in the verse "... the Command is for none but God: He hath commanded that ye worship none but Him: that is the right religion, but most men understand not ..." (Qur'ān, Yūsuf, verse no. 40). The text discloses that a Muslim has no option on the decisions made by God and His Messenger and he is commanded to serve none but God; he is disallowed from deciding on his own in matters already determined by God and the Prophet (peace be upon him), except that he is required to refer to the texts for guidance. The limitation is obvious in the text.

Second is the denial mode (uslüb al-inkār). This refers to denying God and His power and it is replaced by human desire by other than His rulings as the Scripture stipulates, "Do they then seek after a judgment of (the Days of) Ignorance? But who, for a people whose faith is assured, can give better judgment than God" (Qur'ān, al-Mä'idah, verse no. 50). In relation to this, Ibn Kathīr (n. d., Vol. 2, p. 67) remarks that God denies every good for a human being who departs from applying the rule of God and instead follows the opinions, vain desires, whims and fancies and terminologies of people without tracing their origins to basic Islamic legal principles, like the ignorant people (in Arabic, jähiliyyah) did in the past when they passed judgments out of misguidance.

Third is repudiation mode of faith (uslüb nafi al-ìmann). This denial of faith appears in the text by an oath by God on Himself. God is firm in relation to judgments without resistance based on His Prophet's decisions. Whosoever does not judge by what has been decided by the Prophet (peace be upon him) is regarded to have no true faith and this is substantiated in the Scripture that records, "But no, by thy Lord, they can have no (real) Faith, until they make thee judge in all disputes between them and find in their souls no resistance against thy decisions but accept them with the fullest conviction" (Qur'ān, al-Nisā', verse no. 65). In relation to this, Ibn Taymiyyah (1372 AH, Vol. 35, p. 408) argues that it is impermissible for anyone among the Muslims to judge God's creatures, whether they are Muslims or unbelievers except by the laws of God and His Messenger's Patterns. This import is repeated in the Scripture, the Prophet's Traditions, and learned people's statements.

It is in the minds of Muslims that the Muslim community has lived for centuries in the presence of God's laws and there existed the sense of feeling that the rules belonged to God alone till the intellectual onslaughts began with the colonization of Muslim lands. Consequently, European laws entered the Ottoman caliphate whereupon it became weak, its maladies multiplied and enemies advanced with reforms and made people to believe that renaissance would be possible only when man-made laws are adopted by Muslim nations. Consequently, a law was first enacted in $1840 \mathrm{CE}$ in a Muslim country tracing to external sources. It was the Ottoman law of punishments and later other laws were enacted in the caliphate till the laws of Islam were eliminated in $1348 \mathrm{AH}$ (Al-Ashqar, $1406 \mathrm{AH}$, pp. 64-67).

After the collapse of colonial powers, the majority of Muslim countries inherited the positive laws invented by colonialists. French, British and Swiss laws became the sources of laws and legislations in Muslim countries. Gradually, the laws of God disappeared in most of these countries. Individuals played their role in their relations to others, where differences occurred on the laws of God with disdain regarding the pillars of religion, leading to its criticism with strong objections. A group of Muslim scholars has warned Muslims of external influences, cultural and intellectual onslaughts which kindled their religious sentiments and invited them to follow the laws 
of God; thus, a new terminology or al-häkimiyyah, i.e. Sovereignty (henceforth, 'Sovereignty') came into use in the writings of revivalists (Yakān, 1983, Vol. 1, pp. 13-18), particularly Maududi and Sayyid Quțb. Maududi (1397 AH, p. 29) asserts that among the requirements of Godhood is that the rule is only for God where he emphasizes that whosoever has no absolute power, it is not possible for him to be a deity (iläh) and it is not appropriate to consider him as a deity and $\mathrm{He}$ (God) alone ought to be considered as a deity.

Sayyid Quț has written on the issue of 'Sovereignty'. Compared to others, his discussion is extensive, pervasive and provocative. He asserts that 'Sovereignty' is for God alone and none has the right to subjugate people and enact laws. It is the foremost of the characteristics of Godhood for which a believer in God is not challenged, condemned or oppressed for its application, and whosoever challenges the right and validity of 'Sovereignty' and the right of God's subjugation of people and for whatever reasons he legislates laws on his own accord, is regarded as challenging the right of Godhood (Quṭb, $1403 \mathrm{AH}, \mathrm{p} .177)$.

The crucial problem is the spread of terminology which according to some scholars is considered new in religion; it is the result of translating western terminologies and importing them into Islamic heritage. This sweeping remark does not mean that the terminology is dissonant or irrelevant because the sense, origin and meaning of it did exist in religion and it is an integral part of the Oneness of Godhood. Muslim scholars of the past had discussed the concept of 'Sovereignty' and made it mandatory. The problem is the use of the terminology and the understanding of its meaning, not the issue of God's rule. The manner in which it has been explained, though Muslims never dispute it, whether one agrees or disagrees, has resulted in a crisis. When the laws of God disappeared from the lands of the Muslims, the issue of 'Sovereignty' was moulded in a new mode to rejuvenate the concept of 'Sovereignty' in the minds of Muslims so that they could live true Islamic life, like earlier generations had.

According to some Muslim scholars, the issue of 'Sovereignty' is the key ideational root for extremism where the major complaint of Islamic movements and those who resort to extremism is the application of laws other than what has been revealed by God. It is commented that their understanding of 'Sovereignty' is incorrect. Some researchers who articulate on extremism have admonished it. The most significant works that discuss the phenomenon of extremism are al-Hukm wa qa diyyat takfïr al-Muslim and al-Hukm bi ghayrī mã anzala Allāh wa ahl al-ghulūw. Sālim al-Bahansāwī, who witnessed the development of the idea of extremism in Muslim countries, explains the causes for it. According to him, discussions that took place on the issue of 'Sovereignty' in prisons were responsible for sowing seeds of extremism and not the principles or interpretations of Kharijites, as assumed by some researchers. One such example of extremism, according to him, is that one of the prisoners admitted that they have differed with the ruler because he had become a partner to God and subjugated people to obey him and his laws. In other words, God's rule had been replaced by the rule of man.

In observing the phenomenon of extremism, either ideological or practical, it is discovered that most of them are in relation to the issue of the rule by other than what has been revealed by God in Muslim societies. Some examples are provided for clarity. First is charging a resident (muqīm) as an infidel but not an immigrant (muhäjir). This sort of accusation can be referred to some justifying factors among which the land is the land of the unbelief and that the societies are ignorant, unfavourable or unsympathetic to Islamic laws. Every act of extremism is related to the concept of ruling or judging a matter based on other than what has been revealed by God. Second is harsh criticism of rulers. The key reason for this is the alleged infidelity of Muslim rulers due to their rule based on other than what has been revealed by God. Third is extremism in understanding the phenomenon of imitation (taqlid). Imitation of legal rulings of a particular school of jurisprudence (madhhab al-fiqh) or traditions is disapproved by extremists; their understanding of imitation is different, it is absolute obedience or compliance to other than Islamic laws and obedience is not for anyone other than God. Therefore, they charge an imitator (muqallid) as an infidel because he delivers judgments or rules or expresses his opinions and decides on matters based on other than what has been revealed by God, and follows other than the Prophet's teachings.

Likewise, the majority of the phenomenon of extremism has led to the isolation of one another and several educational circles have been convened in relation to the understanding of 'Sovereignty'. When the principal root of extremism is blamed as the result of misunderstanding of 'Sovereignty', then the rule by other than what has been revealed by God is also an element of extremism. As there is false understanding of 'Sovereignty', it is ideal to admonish people with some realities.

The notion that 'Sovereignty' is for God alone does not imply that scores of people should absolutely practise it as though they are the shadow of God or they have acquired the rights of divinity; rather it is obligatory on believers to submit to the idea that 'Sovereignty' is for God, His power and His laws revealed through Prophets 
as the Scripture declares, "God has promised, to those among you who believe and work righteous deeds, that He will, of a surety, grant them in the land, inheritance (of power), as He granted it to those before them; that He will establish in authority their religion, the one which He has chosen for them; and that He will change (their state), after the fear in which they (lived), to one of security and peace: They will worship Me (alone) and not associate aught with Me. If any do reject faith after this, they are rebellious and wicked" (Qur'ān, al-Nūr, verse no. 55). Whenever a remark is made that 'Sovereignty' implies a practice by a group of people with the authority or dominion or supremacy of calling as though they are the shadow of God on earth, this is extremism and the proponents of 'Sovereignty' never claim that they have ever proclaimed it.

The remark that the issue of 'Sovereignty' is the key ideational root for extremism does not mean that remark on 'Sovereignty' itself is extremism or wrong as some scholars have asserted by calling it ('Sovereignty') as an ideational instrument for extremist organizations where it is said that among the instruments (of extremism) is the idea of 'Sovereignty' which is for God alone; their exceeding of proper bounds in relation to it is excessive sickness that originates from ignorance with no limits for it in the interest of mankind and the objectives of revealed laws. The idea propounded by Maududi and Sayyid Quṭ has pervaded thousands of youth and influenced millions. Some scholars have argued that their interpretations are the causes for extremist tendencies. But many have refuted it. Advocating the view that their interpretations have caused damage to society is distortion, deviation or exploitation.

It is asserted that the call for 'Sovereignty' is not alien to Islam. However, Muhammad 'Imārah (1407 AH, p. 95) argues that it is derived from an alien source. He advocates that the feature of 'Sovereignty' in its early development had not been perceived to have any link with Islamic political thought nor was it in the form of Maududi's expression of the recent Islamic thought or necessities of the Islamic renaissance in the framework of Arab community. Indeed, it is an external feature applied to classical heritage and has influenced contemporary human reasoning.

On the contrary, the concept of 'Sovereignty' is repeated in the Scripture and the Prophet's Patterns, though the exact term is not used. The Prophet (peace be upon him) and the early Muslim Caliphs governed societies based on the laws of God where sovereignty was upheld but extremism was tangible in some forms in relation to following the deeds and utterances of the Prophet (peace be upon him) and his Companions. It is possible to identify the impacts of the remark about 'Sovereignty': the rule by other than what has been revealed by God, conviction in this rule has resulted and the call to it by what has been revealed by God. Then, non-responding to this call has resulted in reactions to it, charging one as an infidel and then came, of course, charging the ruler as an infidel as one of the manifestations of extremism.

It is stated that the advocates of 'Sovereignty' are unclear about the motto of the Kharijites and the proclamation of 'Sovereignty' of God by contemporary revivalists. This is what some writers comment in relation to this matter when someone claims that Sayyid Quṭ has influenced people with his desire for this understanding with the outcry of Kharijites' way of living as the foundation of the Umayyad state, i.e. no 'Sovereignty' except for God (Dabāb, 1987, p. 129). However, some of them affirm that the feature of 'Sovereignty' is in itself the motto of Kharijites, (i.e. no rule except for God's) (Al- ${ }^{\mathrm{C}} U$ shmāwī, 1987, p. 28). The difference between why the Kharijites took revenge against ${ }^{\mathrm{C}} \mathrm{Ali}$ and the surrounding conditions for lifting the feature (i.e. no rule except for God's) and its meaning among them are explained next.

In fact, the Kharijites were not resentful against ${ }^{c} A l \overline{1}$ that he ruled by other than what has been revealed by God but they were resentful against him, for he appointed two judges, and this according to their claim was ruling by other than what has been revealed by God and ultimately they conveyed this to ${ }^{\mathrm{c}} \mathrm{Al} \overline{\mathrm{i}}$ when they debated that "you abandoned the dress that God has clothed you and the name by which God has exalted you, you proceeded and judged in relation to the religion of God that there is no rule except for God's" (Ahmad, n. d., Vol. 1, p. 86). The above stand of the Kharijites is undoubtedly the manifestation of extremism because they wished to deprive mankind of the possibility of applying the rule of God and therefore ${ }^{\mathrm{c}} \mathrm{Al}$ responded to them as mentioned below:

"Ali said: Whenever I narrate to you from the Messenger of God (may peace be upon him) believe it to be absolutely true as falling from the sky is dearer to me than that of attributing anything to him (the Holy Prophet) which he never said. When I talk to you of anything which is between me and you (there might creep some in it) for battle is an outwitting. I heard the Messenger of God (may peace be upon him) as saying: There would arise at the end of age a people who would be young in age and immature in thought, but they would talk (in such a manner) as if their words are the best among the creatures. They would recite the Qur'ann, but it would not go beyond their throats and they would pass through the religion as an arrow goes through the prey. So when you meet them, kill them, for in their killing you would get a reward with God on the Day of Judgment" (Muslim, 
1987, Vol. 2, pp. 513-514).

The Tradition which implies that the rule is for God alone is true. It is in the Scripture as it states, "the Command is for none but God" (Qur'ān, Yüsuf, verse no. 40). But its proponents wished to prohibit the arbitration or decision of the people who apply the command of God and this is false. In relation to this, al- ${ }^{\mathrm{c}}$ Askalāni says that the first issue that they confronted with was 'no command except for God,' expropriated from the Scripture but misinterpreted (Al- ${ }^{\mathrm{c}}$ Askalānī, $1380 \mathrm{AH}$, Vol. 6, p. 619). It is appropriate to explain their misunderstanding by referring to texts from the Scripture in which there are responses. The Tradition communicates another theory that religious extremists must be killed for which there is reward from God. It is evident that Islam never allows nor tolerates extremism in any form and Muslims must reject it.

God says, "If ye fear a breach between them twain, appoint (two) arbiters, one from his family and the other from hers; if they wish for peace, God will cause their reconciliation ...” (Qur'ān, al-Nisā', verse no. 35). 'Alī responded to the Kharijites with this verse and said that they were those who infringed the Book of God. The statement of God that refers to Prophet Dāwud says, "O David! We did indeed make thee a vicegerent on earth: so judge thou between men in truth (and justice): nor follow thou the lusts (of thy heart), for they will mislead thee from the Path of God: for those who wander astray from the Path of God, is a Penalty Grievous, for that they forget the Day of Account"' (Qur'ān, $S a \bar{d}$, verse no. 26). In this verse, God has entrusted Prophet Dāwud to realize the significance of applying the Divine command. There are Traditions that speak in relation to understanding the significance of the Divine command (Abū Dāwud, 1984, Vol. 3, p. 1379). This allows people to comprehend the distinction between the features of 'Sovereignty' as currently explained and 'no command but for God' as advocated by the Kharijites. The proponents of 'Sovereignty' never speak negatively to people about the possibility of applying the rule of God but argue for the absolute leadership for the rule of God as one of the requirements of Islam.

\subsection{Shortcomings in the Ideational Structure}

The shortcomings of the extremists' ideational structure are the key factors among the roots of extremism. Keeping in mind the significance of understanding the true message of religion, Muslim scholars have an important role to play in disseminating the knowledge of the principles of Islamic jurisprudence (ușül al-fiqh) which is the ideal methodology to derive rulings with appropriate evidence to avoid excessiveness in religion. This can be confirmed in two aspects. The first is principles of legislation $\left(u s \underline{u} l\right.$ al-tashr $\left.\bar{\imath}^{\mathrm{c}}\right)$ and then methods of deriving rulings and its methodology (turq al-istinbāt wa manāhijuh) (Al-Luwayhaqūi, 1992, p. 112).

The majority of distortions in Islamic creed or Islamic law are due to shortcomings, misunderstandings or flaws. Some examples in relation to the principles of legislation are focused. The first is ignorance in understanding and applying principles of legislation: the Scripture, the Prophet's Patterns, the consensus (Ijmāa $)$ and the analogy (Qiyās). An element of ignorance or deficiency is witnessed in all or one of them when dealing with a specific problem and this causes extremism. The second is deliberate avoidance of benefitting from these principles. The third is the difference of opinion with established methods of scholars or frameworks. They reject one of these sources as it happened among the people who call themselves the 'Advocates of the Scripture' (Qur'anniyyin). They not only reject anything other than the Scripture as the authority but deny the authority of the Prophet's Patterns or refute the solitary Prophet's Traditions in matters of Islamic creed (Al-Luwayhạaī, 1992, p. 112).

Glancing at extremism through the spectrum of knowledge and truth, one observes that there are shortcomings in the ideational structure or basis amidst extremists. Thus, it is possible to deduce through analyzing and evaluating their teachings, interpretations and opinions, that in addition to shortcomings, there are other dimensions of flaws or defects which are elucidated below. They are classified into two aspects (Al-Luwayhaqi, 1992, p. 112).

The first is absolute ignorance. The most pertinent is ignorance of the Scripture, the Prophet's Patterns and objectives of the Islamic law. It is reflected in considering evidence and the necessary rules for deriving rulings or developing laws, understanding remarks and commentaries of scholars and their effects, the Arabic language and its styles, history and the cosmic patterns, situations and their surrounding conditions and circumstances and the position of people and their deeds. The second is shortcomings or flaws in the methodology. The most crucial of it are [1] deviant methodology in understanding texts, [2] the absence of a comprehensive and holistic view, [3] false elucidation, [4] seeking information or deriving lessons directly from the texts, [5] following ambiguous matters, [6] inability to synchronize between evidence, [7] the absence of objectivism, i.e. following vain desires and [8] accepting rulings from non-qualified and controversial legists or jurists and avoiding trustworthy and reliable or legitimate sources (Al-Luwayḥaqīi, 1992, p. 113). 


\section{Psychological Roots for Extremism}

Researchers' perspectives concerning the issue of psychological root may differ. There are several manifestations. The most important question in understanding this root is whether extremism originates from crookedness in psychology of extremism or springs forth from a milieu in which a human being lives. The answer to this question may be resolved as follows.

According to some scholars, extremism is psychological. It is deeply rooted in psychology (Al-Ghazālī, n. d., p. 42). Many researchers endorse this view. They go to the extent of mentioning that studies on psychology and medical psychology provide evidence that an extremist is a sick personality; there are numerous mutual and parallel characteristics between extremists and mental diseases (Ahmad, 1990, p. 112). There are studies in relation to fanatical trends in psychology and their link with characters of a personality. These studies, despite their criticisms, support the precepts of proponents that there is basic foundation in a personality that assists in the development of fanatical trends in him ( ${ }^{\mathrm{c} A b d}$ Allāh, 1409 AH, p. 26).

Some Western researchers accept this viewpoint and even add more clarifications from their perspectives by limiting the features of the spirit of a fanatic which can possibly be applied to the abovementioned principles. The features are [1] seclusion or segregation, [2] completion before time, [3] superiority, [4] policy of aggression, [5] fascism, [6] lack of leniency and forbearance, [7] suspicion, misgiving and overthrow, [8] conspiracy, [9] allegoric and sensitivity to obligation, [10] harshness, mercilessness-insolence and [11] obedience-commitment (Dakmizān, 1409 AH, pp. 58-63). These features are drawn from the examples of fascism in psychology where a group of psychology professors in the American Jewish Committee attempted to understand the causes for the antagonistic trends and absolute obedience of the Germans to Hitler. The researchers viewed fanaticism as restlessness in a given personality fully representing different psychologically gratifying apprehensions or anxieties ('Abd Allāh, 1409 AH, pp. 130-131).

The majority of researchers observe that extremism is a reflection of the circumstances in which a human being lives. One of the professors who specialized in psychological studies remarks that if a human being finds an event that is not in conformity with his thinking or expectation, it unconsciously coerces him to respond or act contrary to it (Al-Luwayhaqīi, 1992, p. 116). Whatever may be the strong defensive factors and whatever may be the strong responses, it will lead to extremism and violence.

According to Fu'ād Zakariyā, the essence in what we call a terrorist in our present age is that in many situations he does not carry or hold psychological formation that directs him to terrorism; however, he is an individual that adopts or embraces a problem that impacts on his behaviour and his option towards a limit that sometimes contradicts with psychological formation. Some Western researchers are inclined towards the opinion that the weapon of charging the unbelief (takfir) actually comes under the strong influence of political, social and cultural oppressions of people and this is demonstrated by some organizations in the Egyptian society (Kaybal, 1409 AH, p. 66).

As the results of this study have become clear to us, what has been written about the psychological roots of extremism is now summarized. First is the presence of a shortcoming or flaw in the psychological structure of an extremist; a matter which is undeniable in totality. The presence of a shortcoming or flaw in the psychological setting is an individual matter. Formation of personality among extremists is psychological, not jointly; it does not imply continuity of this rule in each extremist or in other words, extremism is not developed in totality based on the reason of crookedness. The majority of psychological defectiveness or imperfection is traceable to the depression which a human being is confronted with. A human being is not begotten crooked, twisted, sinuous or tortuous of the psyche but his frame of mind or mental attitude is formulated according to trainings imparted and circumstances in which he faces. The psychological state of mind is present among extremists where they respond to pressures or depressions and results in retaliation, particularly among youth.

Most of the researchers who study extremism do not visualize it from an individualistic perspective. They observe that it is a social problem and various social problems develop in many situations as a result of social pressures or oppressions. These social pressures influence, in most cases, the explanations of the grave sin of societies and deepen their damage. Extremism represents reaction or natural reflection of continuous political, social and cultural problems. In reality, extremists come under severe influences of pressure and there are two sides of it.

The first is the expression of dissatisfaction of this phenomenon i.e. reaction. It is due to imperfect or defective scientific and practical methodology as a great effect for extremists in their influences and endeavours towards extremism. Earlier, those ideational roots have been explained. The second is those problematic phenomena in the psychology of extremists and how those affected by it differ. Between the two, whosoever is stronger and 
powerful in effect and whosoever is more direct in one of the incidents of extremism, he is explosive in action and accumulates tension.

As for illustration of these phenomena and oppressions, the trend among researchers differs in two ways. First is restraining or preventing from oppressions and the phenomena on one matter. It is seen, for example, that some researchers feel that ideational roots for extremism were represented in the 1967 defeat in Egypt. Indeed, ideational roots for the spread of religious extremism are traceable to the crisis of the Egyptian society, particularly in Egypt's defeat in the July 1967 war (Al- ${ }^{c} A r a b i ̄ 1,1987$, p. 2). It has been denied that the roots of extremism were tortures meted out by some of the Islamic organizations as observed by other researchers (Al-Bahansāwī, 1985, pp. 22-30).

Second is the study of the roots of extremism in general. This view has been shared by many researchers (Al-Qaradāwī, 1402 AH, pp. 108-125). This manner is pertinent when it is asserted by scholars of the past and the present that there exists no one single independent reason for the influence which can be held responsible in one form among the many forms of human behaviour ( ${ }^{c} \mathrm{Abd}$ Allāh, $1409 \mathrm{AH}, \mathrm{p}$. 98). The most influential factors and social oppressions that influence the mental attitudes of extremists or those accused of extremism are mentioned next.

\section{Circumstances Causing Extremism in Muslim Life}

According to Muslim researchers who have applied research methods including observations and interviews with scholars and leaders, there are local, regional and global factors or circumstances that contribute to extremism in different parts of the world. Due to some limitations of the current study, only a few are highlighted. The foremost is the absence of God's laws concerning the rule in the majority of Muslim lands where Islamic law is neglected and replaced by conventional laws. Second is the absence of Islam and its true teachings in Muslim countries where Islam in its comprehensive form is not in place. In various aspects of life what a Muslim individual realizes is the absence of holistic Islamic systems addressing all issues from Islamic perspectives. The absence of Islamic systems, according to some Muslims, particularly the youth, gives rise to confrontational and antagonistic attitudes and negative behaviours (Al-Qaradāwī, 1402 AH, p. 108). Muslims believe that the following phenomena cause extremist tendencies.

a. Oppressions of Islamic Movements: Individuals and groups employ force and resort to violence because Islamic movements in some countries deal with oppressions in the form of imprisonments, tortures, killings and exiles. This is one of the roots of extremism where the organic structure of warfare and retaliation by force are instilled (Qutb, n. d., p. 95).

b. Indictment and Contempt: If problems in relation to Islamic movements are resolved in journalism and information media, it can minimize negative trends. Increased intimidations or frightening and inflating accusations without appropriate evidence and justifications, ridicules, scoffing and mocking of fundamental matters on religion are instrumental to extremism (Huwaydī, 1987, p. 216).

c. Restrictions for Islam and Approval for Secular Trends: The freedom to call to the Message of God is curtailed in some Muslim lands. On the contrary, propagandists of secularism and westernization are welcomed and given access to promote irreligiousness and liberalism. This enterprise has made impacts on Muslim propagandists where some plunge into secret unrests, clandestine missions and resort to violence as the methodology (Al-Qaradāwī, 1402 AH, pp. 119-125). In addition, Muslim propagandists are banished or jailed under the pretence of national security. Religious education is made insignificant with emphasis on secular systems of education, science and technology at the expense of religiosity, spirituality, morality and ethics.

d. Moral Deterioration: The process of westernization that sweeps the lands of Muslims spreads vulgar manners, causes deterioration of good character and promotes obscene deeds. Righteous and conscientious people have no ability or power to change it and hence some categorize them as ignorant societies and charge them of unbelief which is one of the manifestations of extremism (Abu al-Khayr, 1980, p. 78).

e. Economic Situations: Social discrimination has a role in the formation of the mentality of extremists. It is possible to identify some bad economic planning and projects. First is lack of fair and equitable distribution of wealth and huge gaps between societies where some youth live without basic necessities. Second is the fall of the value of labour where work is the source of wealth. Unlawful ways of accumulating wealth are rampant and justified. Such things witnessed by people with injustice sow seeds of extremism and terrorism in their psyche (Al-Sharqāwī, n. d., pp. 44-45).

f. Absence of Muslim Scholars' Role: It is possible to identify several dimensions in relation to the absence of the role of Muslim scholars in providing undistorted religious education, interpretation and guidance. What occurs is 
abandonment of important matters or tasks where groups of scholars get rid of the importance of guiding people and instead engage in wasting their time and energy, opening gates for ignorance. In this contemporary era, knowledge of Islamic Sciences is abused to obtain honorific titles. Scholars' deviation from professional pursuit of knowledge and utilization of their profession for temporal ends and not delivering messages which they are supposed to, lead to accusations by extremists. They move in an orbit of rulers who endorse and justify their deeds, decisions, directions and rule even though these are in non-conformity with Islamic teachings (Al-Luwayhaqaī, 1992, p. 121).

g. Westernization and Secularization: Since the end of military colonization and westernization, the processes are still sensed in all dimensions in Muslim countries, directly or indirectly. It is this process of westernization that has propelled people to move forward to various stages of extremism (Sabrī, 1401 AH, Vol. 1, p. 369). Westernization has resulted in a reaction known as extremism according to one religious scholar who has been accused of being an extremist as he says that "it appears to me that extremism will remain in various modes longer or shorter as long as the hegemony of westernization remains, and it will not be weakened except by its own weakness" (Al-Basharī, n. d., p. 61).

h. Political and Military Defeats: The Muslim world has been victimized through numerous political and military defeats. These two dimensional types of defeats have great impacts on the occurrences of extremism and therefore groups of researchers refer to the manifestations of extremist organizations for their reaction which happened after the Egyptian defeat in the 1967 war (Al-Qaradāwī, 1402 AH, p. 117).

i. Conspiracy against Religion: The Muslim community has been dethroned from the community of leadership to the community of following and empowerment of its enemies. This overthrow of the community, as a result of conspiracy, has influenced to a great extent the psyches of Muslims and sowed in their souls elements of extremist tendencies (Jarīshah, 1986, p. 11).

j. Domination of Materialism: Materialism dominates the world for its urban development. Such an emphasis on worldly matters or developments, in most cases, is at the expense of commitment and dedication to religion. This has great impacts on some people leading to extremism (Al-Luwayḥaqīi, 1992, p. 122).

k. Fall of the Caliphate: The united Islamic state or commonwealth or caliphate has collapsed despite ruling the lands of Muslims for centuries. Right or wrong, Muslims believe that this has occurred due to the plots of external forces; external factors had contributed to the fall. This has made great impacts on the psyches of those who stand for extremism. This trend is clear from the writings on the need for an Islamic state by Muslim revivalists of the twentieth century (Al-Luwayhaqaī, 1992, p. 122).

\section{Nature of Extremism in Contemporary Muslim Life}

According to Muslim scholars, extremism occurs within the framework of an ideological or religious movement, regardless of whether it is an elite or people's movement in religion, and others such as sectarian or doctrinal. Its existence in Islamic movements is not a discord but conforms to the incidences of the ideational life of a man (Al-Luwayhaqīi, 1992, p. 124). The knowledge on the nature of extremism is a prerequisite to whatever problem is in existence and its remedy. Without this knowledge, an analyst is in a state of confusion and becomes astray; he cannot cure it. Most of the errors among researchers in relation to this problem are due to the absence of proper understanding of its nature. Hence, it is possible to raise some questions to understand the nature of extremism in order to discover proper answers (Al-Luwayhaqaī, 1992, p. 124).

a. Is extremism an action or reaction? Originally, extremism is a behavioural response and usually it is inclined to the opposite direction or position due to a number of factors, external or internal. It is either internally related to the life of the psyche of an individual or externally related to the influences of a milieu ( ${ }^{\mathrm{c}} \mathrm{Abd}$ al-Jalīl, 1408 $\mathrm{AH}$, p. 20). In most cases, occurrences of extremism are in disturbed environments and this is the reality which is a reaction, not an action. Evidently, extremism, as is obvious from many historical expositions, occurs at the time of severe crises, oppressions and disturbances.

Referring to extremism that occurred during the time of the Prophet (peace be upon him) and the Companions, researchers asserted that it was a reaction against some circumstances, which the extremist felt, were not right. Extremism that contained ideational defects or flaws and deviations from the truth found in the early period may appear in righteous and good milieus of contemporary age, as has happened at the time of the Prophet (peace be upon him).

Extremism is a reaction to a dangerous decision, action, situation, event or incident, whether it is in relation to the reality of a matter or viewpoint of an extremist. One such example of it is the man who opposed the distribution of the booties by the Prophet (peace be upon him) on the day of Hunayn (an expedition) where he 
exceeded the limit in his criticisms and protested against the decision of the Prophet (peace be upon him), assuming that what the latter did was an injustice; had he divided the booties equally between the warriors it would have been justice (Al-Luwayhaqī 1992, p. 125). Another example is of the Kharijites who opposed ${ }^{\mathrm{c} A l \overline{1}}$ as being wrong in his action regarding their claim, particularly in relation to arbitration (al-tahkim).

Deducing from the preceding scenarios, one can consider or tend to agree that extremism is deeply connected to a milieu, situation, social or political condition and it is not a product of a specific thought or an idea. According to experts in psychological studies, when a human being finds an event not conforming to his wish or agreeing with his anticipation, he will react against the event, regardless of whether its defender is strong or the reaction is forceful; this will eventually lead to extremism and violence. This theory has caused researchers to propound and infer that extremism is the opposite action against social or political systems in confronting external or internal crises (Ibrāhīm, n. d., p. 22).

In this contemporary era, extremism occurs in response to what has taken place earlier as a reaction against the odd situations that Muslim societies live in. It is remarked that extremism is a reaction against social or political factors that are responsible for the emergence of organizations imbued with extremist thoughts (Al- ${ }^{\mathrm{c}} \mathrm{Arab} \overline{1}, 1987$, pp. 2-3); the majority of Muslim societies face severe oppressions, social injustices and discriminations, economic disparities, civilizational suppressions and moral decay. The violence spearheaded by those who were accused of extremism is in fact a reaction, not an action. It does not occur instantly nor is it pre-planned but it is a reaction against unacceptable or inappropriate aspect. This can be testified by the history of Islamic revival movements of the twentieth century or during the period of the Prophet (peace be upon him).

b. Is it temporary or permanent? In responding to this question, it is necessary to differentiate between the individuals and the Muslim community. In most cases, the problem is temporary in relation to individuals but to the Muslim community it is permanent. An extremist, in most cases, will end his extremism. The Prophet (peace be upon him) is reported as saying that none will be severe in his religion and this implies that none will be profound or penetrative or fully submerged in religious activities over and above prescription and leave gentleness, except if he is incapable and interrupted or disrupted and overwhelmed. This is in relation to individuals. It is different for the Muslim community. According to some researchers, extremism is a permanent phenomenon in relation to the Muslim community and will expand correspondingly to factors that create disturbances and hurdles.

c. Is it local or global? Extremism is not a local problem confining to one particular country; rather, it is global consisting of Muslim countries stretching from Indonesia to Morocco. Those who follow the Muslim World news in various channels either in the West or East can acknowledge that many of them refer to news about Muslim organizations accused of extremism. Moreover, the Western media highlight it frequently. News is heard about extremism in Nigeria, Egypt, Algeria and other Muslim countries. Regardless of whether any truth lies in it, what is important is that this problem exists on the corridors of the majority of Muslim countries. It is severe in some countries compared to others. This is due to the complexity of the factors in relation to this problem and the weakness or incompetency of the authorities in handling it.

d. Does it originate from Muslim societies or external forces? Some secularists opine that the problem of extremism can be traced to external forces or factors. It is difficult to grasp why they subscribe to this view. It is unknown whether they are biased or genuine. In addition, they attempt to provide a link between organizations accused of extremism and Iran, while others try to establish a link between such organizations and America. Others hold that Gulf countries fund and sponsor activities of extremism. But these are assumptions or speculations and have no evidence. One view is that those who are accused of extremism are from outside Muslim societies. The other is that there are roots in Muslim societies themselves or they are strangers who enter Muslim countries to instil and perpetuate extremism among the locals.

However, the results of a survey show that the majority of Muslim people wish to be moderates. A field study conducted in one Muslim country has discovered that moderates are young and $90 \%$ of them are aged between 20-30 years old; they have obtained higher education and $80 \%$ of them are university students or graduates; they were in agreement with the findings of the study that they were inclined to be moderates. This confirms that the indigenous situations, not imported, have given rise to the problem. There might be some influences with limitations like the Iranian revolution. But it is neither proper to accuse nor possible to trace it to the revolution without evidence. The argument that there was connection between the accused organizations and the Iranian revolution can be refuted on the grounds that those who were accused of extremism were Sunni Muslims with certain ideological commitments, the Iranians who were believed to have influenced others as well as the Shīah Muslims, a different ideological group from the perspective of the above. So the allegation that there is a link 
between them is a matter of claim that is left unproven.

e. Is it individual or collective? There are discourses on whether the phenomenon of extremism is individual or collective. To answer this question, it is important to know the types of extremism which revolve around people. If extremism is completely ideological, it is collective. If it is partially practical, it is individual. Extremism in the life of contemporary Muslims occurs mostly at the collective level. There are greater concerns about complete collective ideological extremism. This does not imply that the existence of individual extremism is denied. As collective or organized extremism is more harmful and devastating than individual extremism, it needs to be diagnosed, treated and eliminated.

f. Is it social or political? According to researchers, the existing trends and the views of researchers have led us to identify five aspects: They are problems of legislation, religion, whims and fancies, civilization and politics. The truth is that there are different dimensions. If the supporting factors in its development phase are diversified, its impact will be more and not just one. It is a problem of whims and fancies because those who are accused of extremism aim at asserting and establishing Islamic elements in correspondence with the gravity of extremism of westernization and secularization which have affected and are affecting the lands of Muslims in terms of religiosity and identity.

It is a civilizational problem because those who are accused of extremism react to the spread and dominance of Western civilization in Muslim countries and they hold that extremism will remain as long as westernization remains (Al-Luwayhaqi, 1992, p. 125). It is a religious problem because the basic claim of those who are accused of extremism is that religion represents everything in life for a Muslim. The religion is extremely important, according to them; it is their priority and their life because they believe that it is comprehensive, addresses every aspect of human life and solves human problems. It is also a political problem because, according to them, politics is an integral part of religion which makes it mandatory to enforce the cosmic law on earth.

No doubt, extremism absolutely poses a great threat to the society in the political dimension and the majority demands of those who are accused of extremism are related to the rule, legislation and judgment based on God's command and man-made laws or systems; the latter should not dominate Muslims at the expense of revealed laws. With this brief reference to issues of extremism, it is possible to establish that the problem of extremism in contemporary Muslim life has different dimensions and it is improper to view it from one perspective only.

\section{Conclusion}

The discourse leads to conclude that extremism has been in existence since the advent of religion and some of the sects resorted to it, creating turmoil in early Muslim societies, particularly among the Kharijites and the Rafidites who exceeded the limits in interpreting religious issues, generating discord due to false explanation of legal rulings. It discloses that contemporary extremism has historical, ideational and psychological roots. There are factors for extremism: internal as well as external. Extremism takes place at individual and collective levels. It is local, regional and global. The absence of God's laws concerning the rule in Muslim lands where they are replaced by conventional laws has resulted in excesses.

Muslims need to understand true Islamic teachings and regard the Prophet (peace be upon him) as the role model who prioritized peace which was transparent from his administration of Medina where the first constitution ensured fundamental rights for all regardless of people's affiliation to different religions. Being compassionate, the Prophet (peace be upon him) tolerated the different religious practices of all people. His rule was balanced and just. No discrimination based on ethnic origins or religious dedications was noticed. The laws of God were the laws of the land. His decisions were treated as final.

This study results in some recommendations. Good examples are available for tolerance and forbearance in Islamic teachings. What is important for Muslims is that they observe religious requirements which advocate peace and not resort to extremism as God explicitly warns the believers not to be extremists. The same admonition is found in the Prophet's teachings where he commanded the believers not to become extremists, including in religious matters. Hence, Muslims have no excuse or justification for extremism; rather they must play a role to curtail it. Under no circumstance can it be condoned. Muslims should never be sympathetic to extremist or terrorist tendencies or motives.

The Muslim Scripture asserts that Islam is a religion of peace. Hence, Muslims are commanded to be peace-loving and peace-enforcing force and moderate. Therefore, it is crucial to understand the teachings and purposes of religion to avoid words and deeds that push towards extremism. Muslims must reject all forms of extremism, promote peaceful co-existence and build global harmony. Maintenance of religious identities or 
application of God's laws or enhancement of religious spiritualties or adherence to Islamic dress code or upholding of Islamic religious cultures and traditions or performances of religious rituals or observances of pilgrimages or offering of animal sacrifices, etc. should not cultivate antagonistic feelings and confrontational attitudes against other communities or religions for the Scripture asserts that Muslims are a moderate and fair nation.

Attempts are made to solve problems of extremism individually by providing opportunities to understand priorities in life. Seminars are convened to create awareness on the need for global communal harmony. Educational institutions conduct intellectual discourses, trainings and courses to enable students to ponder the consequences of extremism and inspire them to educate communities to establish tranquillity and be moderate in discourses and human relations. Muslim scholars deliver sermons to express words of peace, compassion, kindness, uphold religious tolerance, accommodate differences and solve problems through peaceful means. Politicians, community leaders, policy makers and heads of states have the authority to promote peace but unfortunately problems of extremism still exist. Why? Is there any deficiency in managing the affairs? It is essential to find the answers through research. Of course, the discourse unveils that there are problems which have yet to be addressed and solved. For this purpose, the authorities must conduct a comprehensive survey, considering respondents from all segments of societies to discover the true causes. Action can be taken based on findings. Perhaps, relevant or not at this juncture, it may be premature to recommend that Muslim leaders genuinely evaluate the concerns and demands of Muslims and consider their call towards applying the revealed laws in Muslim societies that may probably eliminate extremism, if not minimize it.

\section{References}

`Abd Al-Jalīl, R. (1408 AH). Al-Ta țarruf al-dīnī fì Irān (1st ed.). N.p., Dār al-Ṣaḥwah li al-Nashr.

Aḥmad, Samīr, "Muḥaddidāt al-tațarruf al-dīn̄i fì Misr, Majallat al-mustaqbil al-'cArabī, Markaz al-waḥdah al- ${ }^{c}$ Arabiyyah, Beirut, No.3, February, 1990.

Al-'Abidīn, Z., \& Nā'if, M. A. I. (1407 AH). Al-Hukm bi ghayrī mā anzala Allāh wa ahl al-ghulūw (1st ed.). Birmingham: Dār al-Arqam li al-Nashrwa al-Tawzī $\bar{c}^{\mathrm{c}}$.

Al- ${ }^{\mathrm{c}}$ Arabī Rajā’’ (1987). Al-Tațarruf al-dīnī wa ab ${ }^{\mathrm{c}}$ āduh al-salbiyyah. Al-Qāhirah: Akādimiyyah al-Shurțah .

Al-Ashqar, ${ }^{\mathrm{C}} \mathrm{U}$. S. (1406 AH). Al-Shari ${ }^{c}$ ah al-Ilāhiyyah (2nd ed.). Al-Kuwait: Dār al-Dāwud.

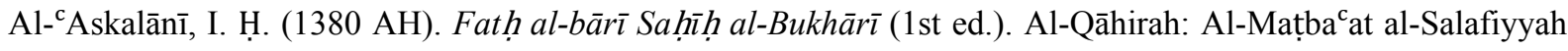
wa Maktabatuha.

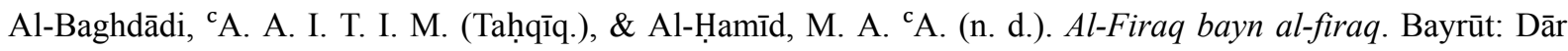
al-Ma ${ }^{\mathrm{c}}$ rifah.

Al-Bahansāwī, S. (1985). Al-Hukm wa qa dịyyat takfír al-Muslim (3rd ed.). ' Ammān: Dār al-Bashar.

Al-Basharī, Ț. (n. d.). Sa Yabqā al-ghulūw ma baqiya al-taghrīb. Majallat al- ${ }^{c}$ Arabiyyah al-Kuwaytiyyah, 278.

Al-Bukhārī. (1983). Saḥ̄ḥ al-Bukhārī (6th ed.). (Muhammad Muhsin Khan, Trans.). Lahore: Kazi Publications.

Al-Dimashqīi, K. A. I. M. I. M. I. ${ }^{c}$ A. F. A. A. (15th ed.). (2002). Al-I qām. Bayrūt: Dār al- ${ }^{c}$ ilm li al-Malāyīn.

Al-Dujaylī. (1393 AH). Firqat al-Azāriqah. Iraq: Mațba ${ }^{c}$ at al-Nucmān.

Al-Ghazālī, M. (n. d.). Hiidhār min al-tadayyin al-maghshush. Majallat al- 'Arabī al- Kuwaytiyyah, 287.

${ }^{c} \mathrm{Ali}$, ${ }^{\mathrm{C}} \mathrm{A}$. Y. (1989). The Holy Qur'an, text, translation and commentary. Maryland: Amana Corporation.

Al-Khayr, A., \& Al-Raḥmān, ${ }^{\mathrm{c}} \mathrm{A}$. (1980). Dhikriyyāt̄̄ ma ${ }^{c}$ jamā ${ }^{c} a t$ al-Muslimīn (2nd ed.). Al-Kuwait: Dār al-Buhūth al- ${ }^{\mathrm{c}}$ Ilmiyyah li al-Nashrwa al-Tawzī' .

Allāh, 'A., \& Sayyid, M. (1409 AH). Al-Ittijāhāat al-ta cașșubiyyah. Al-Kuwait: Al-Majlis al-Wațanī li al-Thaqāfah wa al-Adab wa al-Funūn.

Al-Mawdūdi, A. A'. (1397 AH). Al-Muștalaḥāt al-arba ča fì al-Qur'ān (6th ed.). Al-Kuwait: Dār al-Qalam.

Al-Qaradāwī, Y. 'A. A. (1402 AH). Al-Ṣaḥwah al-Islāmiyyah bayn al-Juḥūd wa al-tațarruf. Qatar: Ri’āsat al-Mạ̄ākim al-Shar ${ }^{\mathrm{c}}$ iyyah wa al-Shu' ūn al-Dīniyyah.

Al-Sāmrā'̄. (1986). Al-Takfīr Judhūruhu asbābuhu wa mubarrirātuh. Bayrūt: Al-Manārah li al-Ṭibā'ah wa al-Nashr wa al-Tawzīi .

Al-Shahristān̄̄, A. A. (1381 AH). Al-Milal wa al-nihal. Al-Qāhirah: Sharikah wa Mațba ${ }^{c}$ at Mușțafā albān̄̄.

Al-Sharqāwī, ${ }^{c}$ A. A. (n. d.). al-Irhāb. N.p.: N.p. 
Al-Shawqānī, M. I. A. I. M. (n. d.). Nayl al-awtar sharh muntaqa al-akhbar min ahadith sayyid al-akhbar. Al-Qāhirah: Mațba ${ }^{c}$ at Mușțafā albānī.

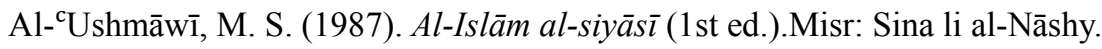

Dabāb, M. Ḥ. (1987). Sayyid Quṭ̂ al-khitāb wa al-Idiologiyyah (1st ed.). Al-Qāhirah: Dār al-Thaqāfah al-Jadīdah.

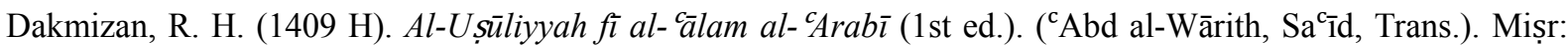
Dār al-Wafā.

Dāwud, A. (1984). Sunan Abū Dāwud (1st ed.). (Ahmad Hasan, Trans.). Lahore: Sh. Muhammad Ashraf.

Huwaydī, F. (1987). Al-Tadayyun al-manqūsh. Al-Qāhirah: Akādimiyyah al-Shurțh.

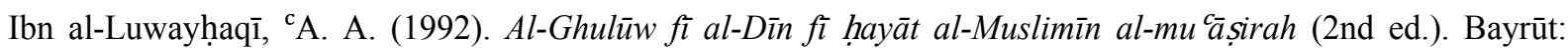
Mu'assasat al-Risālah.

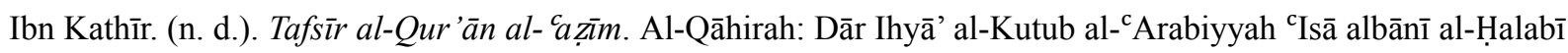
wa Shurāka'uh.

Ibn Taymiyyah. (1372 AH). Majmū $\bar{u}^{c}$ at al-Fatāwā. Al-Riyāḍ: Mațba at al-Riyāḍ.

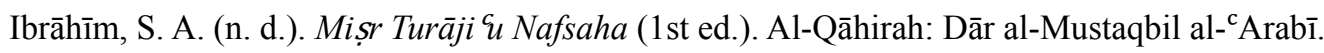

'Imārah, M. (1407 AH). Al- '́ Almāniyyah wa Nah datuna al-hadīthah (2nd ed.). Al-Qāhirah: Dār al-Shurūq.

Jālī, A. M. (1406 AH). Dirāsah 'can al-firaq fĩ tārikh al-Muslimīn al-Khawārij wa al-Shī ah (1st ed.). Al-Riyāḍ: Markaz al-Malik Faysal li al-buhūth.

Jarishah, ${ }^{\mathrm{C}} \mathrm{A}$. (1986). Al-Ittijahāt al-fikriyyah al-mu āṣsirah (1st ed.). Al-Qāhirah: Dār al-wafā'.

Jārullāh, M. (n. d.). Al-Washī ah fì naqd aqā'id al-Sh̄̄ ah. Al-Qāhirah: Maktabah Kulliyyat al- Azjhariyyah.

Kaybal, J. Tr., \& Khuḍr, A. (1409 AH). Al-Nabiyy wa al-Fira wwn. N.p.: Maktabat Madbūl̄i.

Muslim. (1987). Saḥīh Muslim (Abdul Hamid Siddiqi, Trans.). Lahore: Muhammad Ashraf Publishers and Booksellers.

Quțb, S. (1403 AH). Muqawwimāt al-tașawwur al-Islāmī (1st ed.). Al-Qāhirah: Dār al-Shurūq.

Quțb, S. (n. d.). Li mādhā $A^{c}$ damūnī. London: Al-Sharikah al-Sữūdiyyah li al-Abhāth wa al-Taswīq al-Duwaliyyah.

Șabrī, M. (1401 AH). Mawqif al- caql wa al- cilm wa al- ālam min Rabb al- călamīn. Bayrūt: Dār Ihỵā’ al-Turāth al- ${ }^{\mathrm{C}} \mathrm{Arabī}$.

Yakān, F. (1983). Al-Mawsū̄ cat al-ḥarakiyyah (2nd ed.). ${ }^{c}$ Ammān: Dār al-Bashīr li al-Nashrwa al-Tawzī̄ .

Zakariyā, Fu'ād, "al-Tațarruf al-siyāsī al-dīn̄i: al-Judhūr al-wāqi' al-mutaqbil,” No 8, December 1985.

\section{Copyrights}

Copyright for this article is retained by the author(s), with first publication rights granted to the journal.

This is an open-access article distributed under the terms and conditions of the Creative Commons Attribution license (http://creativecommons.org/licenses/by/3.0/). 